\title{
Retooling Engineering for Social Justice: The use of explicit models for analytical thinking, critical reflection, and peer-review in Swedish engineering education
}

\author{
Katarina Larsen* and Johan Gärdebo
}

\begin{abstract}
*KTH Royal Institute of Technology, Stockholm, Sweden, katarina.larsen@abe.kth.se - KTH Royal Institute of Technology, Stockholm, Sweden, johan.gardebo@abe.kth.se
\end{abstract}

This paper engages with how engineering education in Sweden have been retooled towards literacy in social justice. To achieve this, the authors used a set of pedagogical tools aimed at analytical thinking, critical reflection, and peer-review by students. The students were asked to use the tools in the course to critically analyze social justice in the city planning of twentieth century Stockholm, Sweden. This included, for example, national identities, social engineering, and politics that shaped Swedish society. The authors conducted a textual analysis of student essays on social justice that indicate increased social justice literacy and a shift towards the practices of engineers' work with city planning. The study concludes by discussing conditions for engineering students to gain familiarity with formats used for critical reflection within the humanities.

KEYWORDS: engineering education, scaffolding, analytical thinking, critical reflection, peer review, social justice, retooling

\section{Introduction}

It's the start of a new semester at the KTH Royal Institute of Technology in Stockholm, Sweden. The students come here from Berlin, Burkina Faso, Buenos Aires, Cape Town, Copenhagen, New York, Delhi, Beijing, Istanbul, Tokyo and Paris. As they gather in one of the larger auditoriums on campus, we the teachers ask them about previous studies. The two things they have in common is also the focus of this article: all are students of engineering, and; none of them have participated in smaller seminar groups before.

Our course, Swedish Society, Culture and Industry in Historical Perspective (SweSoc), was developed for the hundred-or-so international students coming to KTH annually. We provide them with both a curriculum that introduces the engineering students to theoretical concepts, such as social justice in Swedish society, and; pedagogical tools with which to organize their studies and thinking. Social justice and tools for thinking constitute "literacies" in engineering education, which according to CummingPotvin and Currie (2013:26) have changed from initially referring to reading and writing skills towards focusing on how students learn to learn.

We will describe the new literacies as part of a process in engineering education that historian of technology Rosalind Williams has coined "retooling". The tools used for engineering education are rearranged as a result of the students coming from more diverse backgrounds than before and the engineering problems, like social justice, are increasingly complex to solve. We have here sought to make the concepts of analytical thinking, critical reflection, and peer review into tools, meaning explicit models, used for introducing students to social justice.

The approach used in this paper is to analyze how students demonstrate literacy of these tools through peer review and written essays. In particular these focus on excursions to suburbs in 
Stockholm (Husby and Hammarby Sjöstad) in relation to readings and reflections about the concept of social justice. The purpose of this article is to provide you, the reader, with two things: a review of social justice in engineering education, and; a set of tools for humanistic thinking to retool the engineering curricula.

\section{Background: Engineering education}

\section{Social Justice}

What is the role of social justice in engineering education and how should students understand it? These are questions that were central to the course SweSoc and will be developed here in order to situate some of the programmatic proposal made in the US and Europe to reform education. While the concept of justice has been analyzed since the dawn of Western political philosophy, we here provide a brief review of different interpretations as an illustration of how each perspective would require different sets of literature to be used in a course such as SweSoc.

The political philosopher Rawls formulated two principles, the first concerning structures that shape the distribution of opportunities, and the second being the difference principle. The difference principle is relevant to engineering education as it states that changes in society are just insofar as they improve the conditions of the very poorest. Safeguarding justice as fairness, according to Rawls, is the role of institutions, of which education is one. He stated,

The natural distribution is neither just nor unjust; nor is it unjust that persons are born into society at some particular position.... What is just and unjust is the way that institutions deal with these facts. (Rawls 1971: 87)

Let us look closer at the difference principle when considering the claim by economic historian Deidre McCloskley that innovation has historically improved conditions for the very poorest. McCloskley's precondition for innovation is liberty and respect for the individual. These are liberal preliminary agreements for achieving justice and cannot be unmade by Rawl's Marxist redistribution of wealth (McCloskley, 2010:25-26, 73).

Geographer Sarah Whatmore in turn discard Rawl's Marxism and McCloskley's liberalism as universalist notions of rational humans, which she replaces with an ethics of not only social but environmental justice that includes non-humans as well (Whatmore, 2002: 147-148). In turn, philosopher Laurens ten Kate (2011) historicizes principles of justice altogether as an effort to restore rationality as a whole following the disasters of the Second World War, the Holocaust and the Cold War. The end goal was never the principles themselves, but to re-establish some form of contract for humans and others to live together globally (Willem et al., 2011: 104-105).

Correspondingly for societal planning in the US and Europe, engineering education has been embroiled in debates about various programmatic proposals for how to include social justice in engineering education (Lang et al., 1999), how to establish a social contract whereby science can help address societal challenges (Mauser et al, 2013; Gibbons, 1999) and training collaborative knowledge production could in turn make it socially robust (Lubchenco, 1998 ; JIIP, 2012).

Regarding the new skills required to address the new problems, there have been numerous suggestions on how to change engineering education: networked literacies enable use of new media and cross-cultural competencies (IFTF, 2011); metacognition support awareness of how you know what you know (Knight \& Yorke, 2004); and the grand challenges of engineering. 
In the world of today, many of engineering's gifts to civilization are distributed unevenly.... Countless millions have virtually no medical care available, let alone personalized diagnosis and treatment.... So in pursuing the century's great challenges, engineers must frame their work with the ultimate goal of universal accessibility in mind. (NAE, 2008: 6)

While the US National Academy of Engineering hoped the grand challenges would reassert the social relevance of engineering, numerous scholars have criticized them for keeping with a traditional view of engineering (Erin Cech et al., 2013 ; Nieusma \& Tang, 2012). Rather than examining a change in education, the US is believed to suffer from a chronic shortage of engineers, which in turn is a threat to the country's economic growth, and international competitiveness" (Sochacka et al. (2014 ; cf. Walther et al., 2013).

Also the European Union has employed a similar policy rhetoric as that found in the grand challenges, which has repercussions in European higher education: a "scarcity of engineers" needed to solve complex challenges (FEANI, 2007); complex societal problems in turn require demand-driven "technological solutions" (JIIP, 2012: 17).

Critique of the European Union's proposal has focused on shifting to new pedagogical models that explicitly posit learning outcomes of disciplinary and professional knowledge (Edström \& Kolmos, 2015; CDIO, 2015). One study in particular emphasized affective dimensions of engineer social justice, like recognizing diverse stakeholders' points of view, exercising independent thought and judgment, as well as the cognitive dimension of selecting among several critical questions to be addressed (Niewoehner, 2006). Recently there have also been concerns regarding source critique and the ability (or lack thereof) to distinguish between advertisement and news (Wineburg and McGrew 2016).

In 2015, the Swedish Government made "critical reflection" a criterion of the degree ordinance for Swedish engineering education, outlined both as part of the engineers' "competence", and furthermore included social and ethical aspects in the category "judgment". For the degree Master of Science in Engineering, the ability to demonstrate analytical thinking and critical reflection, in relation to social aspects, is said to be crucial for engineering (Swedish Higher Education Ordinance, 2015, see appendix 1 ; cf. Kabo et al, 2012).

Swedish evaluations of engineering education have also pointed out that plans to address societal challenges lack a perspective on sustainability and related issues of social and environmental justice (Enelund et al., 2013; Svanström et al. 2012; Högskoleverket, 2006; UKÄ, 2013). Social justice literature from Sweden emphasizes environmental justice as an example of the tensions existing within sustainability discourse, rather than the consensus described in engineering plans that juxtaposes economic, social and environmental aspects. Planning made in the name of sustainability has uneven or unjust effects on different socioeconomic groups, which has become apparent in several of Stockholm's city planning projects (Bradley at al., 2008).

\section{Retooling}

How do debates on social justice in philosophy, policy, and pedagogy relate to how we wanted to work in course SweSoc? To understand this we will now address a branch of scholarship that discusses the role of engineering education at an institutional level. These accounts are usually produced in connection to anniversaries at technical universities, for example when Drexel University celebrated its 125-year anniversary and several scholars acknowledged early efforts to include Humanities (the arts) as a means to address the new societal challenge of constantly changing technology. "The New Education", proposed by New York lawyer and politician Chauncey Mitchell Depew in 1893, would 
give students "training with machines, in drawing and scientific principles, as well as in the arts" (Depew, C. M. 1893:21-22 ; Falcone et al. 2016).

The most comprehensive treatment of changes in engineering education is by Williams (2002) on how the Massachusetts Institute of Technology (MIT), US Cambridge, in late twentieth century redefined the role of engineering. Williams assert that "Engineers solve problems", but then asks, "What are the problems?" As humans have so vastly engineered the earth so as to mix technology and nature, we keep running into ourselves. Engineering is no longer about shaping nature but about managing a selfmade habitat (Williams, 2002:23-24, 28).

But how should engineers solve problems of technology when technology has also displaced engineering? Global networks of technological and economic power now shift employment to individualized efforts as large corporations or government institutions weakened. With increasing emphasis on self-promotion, engineering students are required to learn human skills in addition to technical ones (Williams, 2002:58-59, 81).

At MIT, engineers enjoy making things. They "tool". And by tooling away they restructure their own habitat. But in a reflexive world, engineering is more complex than making things. Engineers have to retool, which Williams suggest is to understand engineering as a profession - a profession that starts in engineering education (Williams, 2002:28).

One output of Williams' urge for retooling was to establish a course on the history of engineering education at MIT. Historian of technology Arne Kaijser moved from KTH in 2004 to become a guest researcher at MIT. During his time there he took interest in how courses brought humanistic analysis and reflection into engineering education. Kaijser had previously formulated a proposal for reorganizing engineering education at $\mathrm{KTH}$,

The students are not encouraged to think critically or questioning.... One indirect consequence of the authoritarian form is that the engineering students are lulled into a false sense that most problems they will face in their future professional life have an exact solution: it is just a matter of finding the correct equation to apply. (Kaijser, 1998)

Upon returning to KTH, Kaijser developed the course SweSoc based on his experiences at MIT. His aim was to relate engineering education to societal development in Stockholm and Sweden. When we the authors inherited Kaijser's course SweSoc, the question is no longer why the arts are part of making engineering societally relevant. The question is how such an education should be organized. The work begun by Williams and Kaijser towards retooling engineering have in turn encouraged us to question the tools, the methodologies or explicit models, by which the humanities can address social justice in engineering education. The following section describes how we introduced and studied tools for analytical thinking, critical reflection, and peer review to the students in the course SweSoc.

\section{Methodology}

\section{Explicit Models for Analytical Thinking, Critical Reflection and Peer Review}

SweSoc is a course at KTH that provides tools for engineering students to practice literacy in social justice through analytical thinking, critical reflection and peer review. The learning objectives required that the student: 
I. Outline and demonstrate knowledge on the main characteristics of the "Swedish model" (i.e. political system, welfare state structure and neutrality/non-alignment policy),

II. Outline and demonstrate knowledge on the general development of Swedish industry and technology in the post-WWII period,

III. Outline and demonstrate knowledge on the basic characteristics of Swedish city planning during the post-WWII period, and,

IV. Demonstrate analytical reading and writing, including reflecting, referencing, reasoning and deconstructing analytical questions central to the course content.

We wish to draw attention to the fourth objective, which we added to the course in order to introduce the tools, the explicit models, for students to use when solving questions through readings, excursions, seminars, and peer review. Due to the large number of students participating, it was central to facilitate student activation before, during and after the seminars as a means for them to self-assess their training. We will describe each of the tools in turn.

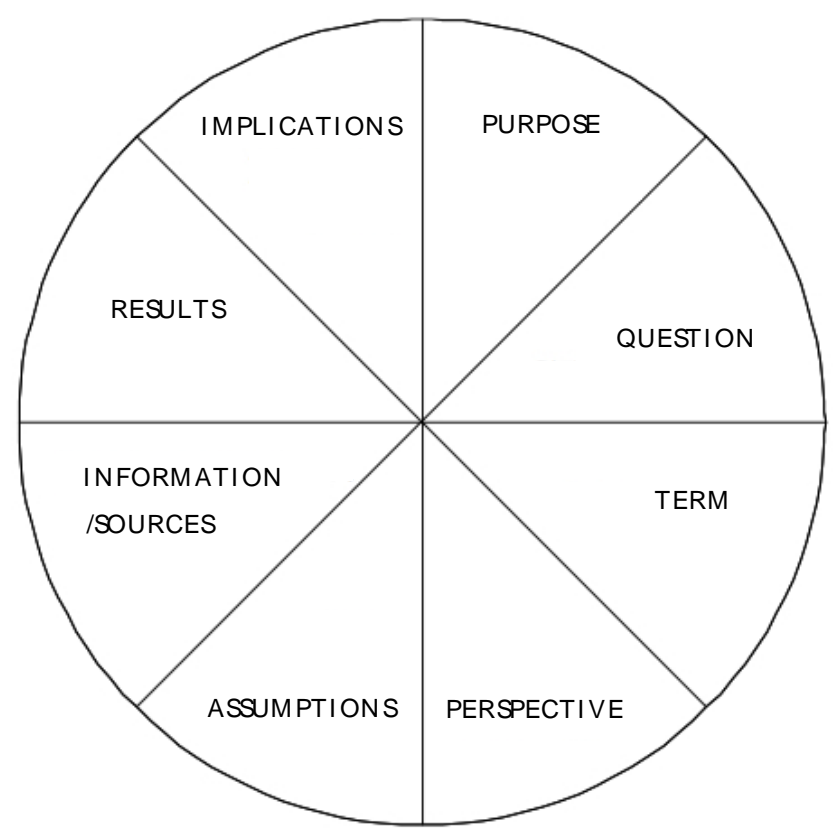

Figure 1. Elements of analysis (Source: Course Material, 2014)

First, we asked students to presume that thinking "generates purposes; raises questions; uses information; utilizes concepts; makes inferences; based on assumptions; that generates implications and; embodies a point of view" (Richard \& Elder, 2005). Students were to create analytical overviews of the course questions by dividing the readings, lectures, and excursions into elements of analysis, as seen in Figure 1.

Secondly, we met students at seminars to facilitate critical reflections about the texts, see Figure 2 . We instructed students to reflect about the method, empirical design, writing style as well as the novelty of the text with respect to other texts on the course. The precursor to the tools is derived from early Socratic dialogues where a students' thinking develops through increasingly refined questioning. 


\begin{tabular}{|l|l|}
\hline METHOD: & NOVELTY: \\
Strength/weakness of approach used? & Why is the text interesting and novel? \\
\hline EMPIRICAL DESIGN: & WRITING STYLE: \\
Alternative ways to carry out study? & Alternative ways to write the paper? \\
\hline
\end{tabular}

Figure 2. Critical reflection on results in texts (Source: Course material, 2014).

Thirdly, students had to explicitly use analytical thinking and critical reflection when giving peer review to texts of other students. These texts were central to answering questions of the course. The peer review had four steps:

1. The student wrote a text using course content to answer a question relating to one of the course's learning objectives.

2. The student uploaded the text to SweSoc's web portal and downloaded two texts uploaded by other students.

3. The student used the explicit model for analytical thinking and critical reflection to give peer review on other students' texts, then uploaded these to the web portal.

4. The student received peer review from other students on the text and feedback from the teacher on their peer review.

Peer review requires active student participation that makes students aware of their own learning processes through involvement in other students' learning (cf. Biggs \& Tang, 2007: 64, 79; Elmgren \& Henriksson, 2010; Harvey, 2013; Healey et al., 2014). To understand the role of peer review in retooling engineering education, we draw upon Lev Vygotsky's social-historical theory of cognitive development. Vygotsky emphasized tools as central to shaping human skills and thinking. Vygotsky based his concept of "tool" on Friedrich Engels' work for how material tools influenced speech development. Vygotsky expanded the definition of a tool to refer to enablers of abstract thinking, whereby a tool is an explicit model for how to think, write and speak, that eventually leads to thinking about thinking, i.e. metacognition, or self-assessment (Engels, 1925; Vygotsky, 1978). Vygotsky argued that students attain self-assessment within their zone of proximal development. The zone refers to all functions that are within the students' reach today, if supported by instruction, but that they can grasp themselves tomorrow, without instruction (Vygotsky, 1978).

Vygotsky's theoretical point is that tools for analytical thinking, critical reflection, and peer review serve as scaffolds to be put around the learning situation to support the students learning. We therefor used peer-review both as a means for students to give or get individual feedback to and from each other but also to demonstrate and understand analytical and critical readings of the course content. This process of learning by giving feedback contributes to students' self-assessment when comparing their own writing to that of others by using a set of criteria.

The tools for analytical thinking, critical reflection, and peer review serve as introductory, simplified, versions of entire fields of inquiry in the humanities and social sciences (cf. Cottrel, 2005; Elder \& Richard, 2007; Lagerqvist, 2010). We do argue, however, that introductory models should be explicit and limited in complexity so as to promote clarity and application of their use. 


\section{Discussing and Experiencing Social (in)Justice in Stockholm: Husby and Hammarby Sjöstad}

We combined several forms of educational activities to support different types of learning, for example visiting areas of city planning to learn about these on site (cf. Lave \& Wenger, 1991). In this way we hoped to combine the tools for thinking, reflecting, and reviewing not only to texts but also to discussions at seminars and excursions to the suburban settings of Stockholm, see Table 1.

We selected the suburbs of Husby and Hammarby Sjöstad as two examples of social engineering in Sweden. The Swedish government planned Husby in the 1970 s to be a socially sustainable community, where Swedish citizens would work, live, and consume services and goods locally. Husby earned international renown as being one of the great progressive housing projects of the late twentieth century. But then several of the work opportunities were outsourced during Sweden's structural crises of the late 1970s onwards. The new residents of Husby were primarily migrants and refugees, for whom Stockholm City provided little support to integrate. While these changes occurred in Husby during the 1990s, Stockholm City by contrast invested heavily in rebuilding its old southern shippingand wharf-districts into a new district, Hammarby Sjöstad, that it envisioned would become an ecofriendly residency. Environmental sustainability also meant social gentrification, as integrated Swedes moved from areas of city planning, like Husby, to new ones like Hammarby Sjöstad.

The breakdown of planning in Husby is synonymous for a lack of dialogue between engineering decision-makers and the inhabitants. Riots in and around Husby 2013 made these misalignments all the more apparent. In interviews, residents of Husby described the underlying reason for the riots as a failure of democracy, the (mis)conduct of police, the dismantling of city planning in Husby and, as a combination of these factors, resistance by youth to what they considered racism in Swedish society (de los Reyes et al., 2014).

\begin{tabular}{|l|l|l|l|}
\hline $\begin{array}{l}\text { Course } \\
\text { activities }\end{array}$ & \multicolumn{1}{|c|}{ Topics } & \multicolumn{1}{|c|}{ Analytical model } & \multicolumn{1}{c|}{ Activity } \\
\hline Seminar 1 & Environmental justice & $\begin{array}{l}\text { Team discussion: introduce } \\
\text { critical-analytical reading }\end{array}$ & $\begin{array}{l}\text { Team discussion } \\
\text { instructions by seminar } \\
\text { leader }\end{array}$ \\
\hline Seminar 2 & $\begin{array}{l}\text { Peer-review - self } \\
\text { assessment }\end{array}$ & $\begin{array}{l}\text { Part 1: write text + peer- } \\
\text { review }\end{array}$ & $\begin{array}{l}\text { Reflect and discuss } \\
\text { improvements according to } \\
\text { criteria in model }\end{array}$ \\
\hline Seminar 3 & $\begin{array}{l}\text { Read and apply critical- } \\
\text { analytical model }\end{array}$ & $\begin{array}{l}\text { Course evaluation as } \\
\text { feedback and self } \\
\text { assessment as learning }\end{array}$ & Oral presentation \\
\hline suburbs & $\begin{array}{l}\text { Segregation, social and } \\
\text { environmental } \\
\text { sustainability }\end{array}$ & $\begin{array}{l}\text { Situated learning field trip } \\
\text { to suburbs of Stockholm }\end{array}$ & $\begin{array}{l}\text { Visit to NGO, walking tour in } \\
\text { Husby and Hammarby } \\
\text { Sjöstad }\end{array}$ \\
\hline Lectures & $\begin{array}{l}\text { City planning, Stockholm } \\
\text { City building regimes }\end{array}$ & $\begin{array}{l}\text { Analytical question + } \\
\text { required reading for each } \\
\text { lecture }\end{array}$ & $\begin{array}{l}\text { Reading by analytical } \\
\text { question + Q\&A lecturer } \\
\text { interaction }\end{array}$ \\
\hline
\end{tabular}

Table 1: Overview of course activities, topics, and analytical model

Our students read about Swedish city planning while also visiting both Husby and Hammarby Sjöstad. We asked them to include both readings and visits as part of their discussions and writings. Local organizations and other researchers of city planning supported the students as guides while reviewing the many demographic and societal changes which the residencies had undergone since the 1970s onwards (cf. DN, 2014). We encouraged students to refer to these settings and conditions when answering examination questions, for example, 
Who can use cities and systems? What role is played by identity, city planning, industry and infrasystems? How are these shaped, influenced and changed and by whom?

For students to think of city planning as an issue of social justice, we encouraged them to rethink concepts like infrasystems and structures in relation to changing social conditions in residential areas. Firstly, how do you plan for systems of telecom, electricity, roads and railroads or waste and water management when constrained by existing infrastructures, like the old wharfs of Hammarby Sjöstad? Secondly, how do you remodel apartments to accommodate new groups of residents from socio-economic groups with different needs compared to needs identified when the housing was first planned, like in Husby? Thirdly, how do you as a planner access networks of residents who have local knowledge and experience of the area that you are planning? And fourthly, how do you assess national identities or media descriptions of residents, and what comparisons could the student make to their home country?

\section{Methods for studying analysis and reflection about social justice in student course essays}

We employed textual content analysis to study how students used the tools of analytical thinking, critical reflection, and peer review in conducting their course essays, which was their last assignment in SweSoc. Textual content analysis requires an in-depth reading of narratives and arguments presented in texts. For example, some studies seek to understand how arguments and issues are portrayed in texts in different media forums (Sochacka et al., 2014), or in discourses of policy documents for city planning (Vaara et al., 2010). For quantifying the textual content analysis, we relied on the software NVivo, version 11 . In total, we received and analyzed 72 course essays, which amounts to a third of all students of the course. ${ }^{1}$ We analyzed the essay content with respect to:

1. If and how the students wrote analytically about arguments in essay assignments

2. If and how the students reflected critically on questions of social justice, particularly course content relating to Husby and Hammarby Sjöstad, in the written essays

We examined if and how the students explicitly elaborated essay arguments to answer questions about social justice. We also studied how students exemplified their arguments using experiences and impressions from excursions to Husby, Hammarby Sjöstad, or other suburbs. The student could choose to write essays on different topics addressed during the course, for example the internal and external factors influencing the Swedish welfare model, climate change policy or city planning. The student was required to demonstrate both analytical thinking of course content and critical reflections, for example when visiting areas of Stockholm during excursions.

Our analysis included three steps: 1 ) in-depth reading of essays; 2 ) word-tree contextualization of terms used in course essays; and 3) qualitative interpretation of terminology used and word-tree output. By combining textual analysis and in-depth reading, we assessed how students exercised analytical thinking and critical reflection around questions of social justice in their essays. See Appendix 2 for word trees analyzing student reflections on their excursions to the suburbs Husby and Hammarby Sjöstad. These are used to identify key terms used when students discussed these excursions.

\footnotetext{
1 Since the course essay is not mandatory, but can improve the student's grade, the number of students writing the essay in SweSoc is historically less than $50 \%$.
} 
After word trees were mapped out and the central terms identified, we used these to guiding a close reading of the written essays to qualitatively interpret the use of these terms. We focused on how Husby and Hammarby Sjöstad were used as empirical examples when discussing social justice, city planning, and the Swedish welfare model. We provide excerpts of such student reflections below to illustrate how they discussed this in relation to the excursions:

"Furthermore, institutions like schools are at much lower levels in suburbs like Husby. So even in a rich and high developed city like Stockholm, not everybody has access to the same "systems"."

"Our excursion to Husby, for example showed that the basic plan of an ABC-suburb is not always working anymore today."

"The urban planners presented the harsh reality of their planning: that the members of poorer, more immigrant communities (such as Husby...) were not being taken into account during planning."

The examples above highlights reflections by students about accessibility, how former planning required adjustments, and the challenges that planners faced in practice when attempting to address challenges of matching planning practice with real life condition and challenges in suburbs. These reflections about social justice brought about the realization that a "highly developed city like Stockholm" also restricted access for certain groups of citizens. Our interpretation of such results is developed further in the next section.

\section{Results}

\section{Analytical thinking and critical reflections in student writing}

From the students' arguments about social justice in Stockholm's city planning, we identified a set of narratives about Husby and Hammarby Sjöstad that each relied on certain empirical examples to discuss how social justice related to city planning (see Table 3). Students also made reference to the Swedish welfare model, climate change policy, and in the case of Hammarby Sjöstad to ecological sustainability and eco-housing. We related these to social justice, for example, in terms of access by residents in Husby to the high-tech labor market.

\begin{tabular}{|l|ll|}
\hline \multicolumn{1}{|c|}{ Husby } & \multicolumn{1}{|c|}{ Hammarby Sjöstad } \\
\hline $\begin{array}{l}\text { Swedish welfare model: historical } \\
\text { development }\end{array}$ & $\begin{array}{l}\text { Transforming old industrial area to eco- } \\
\text { friendly neighborhood }\end{array}$ \\
\hline $\begin{array}{l}\text { Suburbs created in ABC-model today new } \\
\text { needs of immigrant residents }\end{array}$ & $\begin{array}{l}\text { Eco-houses and recycling (technical } \\
\text { description of solutions) }\end{array}$ \\
\hline $\begin{array}{l}\text { Segregation, immigrants' housing situation } \\
\text { in suburbs }\end{array}$ & $\begin{array}{l}\text { Green living in wealthy neighborhoods not } \\
\text { accessible to majority of people }\end{array}$ \\
\hline $\begin{array}{l}\text { Social justice: residents in Husby not } \\
\text { working in IT-sector in nearby Kista }\end{array}$ & $\begin{array}{l}\text { Environmental justice: Protection of } \\
\text { resources (recycling, eco-friendly, etc.) }\end{array}$ \\
\hline
\end{tabular}

Table 3. Results from textual content analysis. Analysis of students' reflections about excursions using the terms: Husby/Hammarby AND social AND justice.

The analysis of essay themes that related to excursions revealed that the excursion to Husby raised questions about social justice and segregation and motivated the students to write down their own 
experiences from the visits. The excursion to Hammarby Sjöstad triggered a broader set of questions about urban regeneration, engineering solutions for eco-efficient suburbs as well as questions about environmental justice.

Student reflections identified both practical challenges for engineering in contemporary planning and wider societal challenges in Sweden. In particular, the students used excursions to empirically exemplify aspects of social justice, for example:

- how to balance social and environmental justice in city planning, including what to do about the gentrification of industrial sites designated as areas for eco-development

- suburban segregation and the challenge of responding to new needs of residents with changing ethnic and demographic composition

- planning "failures" where stakeholder groups were not involved early in the process to ensure awareness of which groups would move into the area

- how planning ideals changed over time and how actors enforced city building regimes affecting residents in the city center and suburbs

As the students relied on the tools to articulate arguments about social justice, they focused on what this meant for the day-to-day practice of the engineer. Rather than planning how to distribute the gifts of engineering, the students reflected on how to combine readings with excursions to relate their work to the context and residents.

Another theme in the students' reflections was the relationship between city planning and national identity (e.g. assumptions about Swedes being a nature loving people). For these arguments, students relied on course readings alone, and were not able to articulate reflections on what this meant for the role of engineers working with social justice.

One conclusion we take from this analysis is that analytical tools should be combined with an empirical context in order for students to question the how engineering influences decision-making. We argue that the concepts of meta-cognition and development of literacy are central here for a discussion about future skills of engineers in facing complex challenges, such as integrating social justice in city planning or the development of existing infrastructures in urban contexts.

\section{Arguments in essays: revisiting proximate zones}

Earlier we mentioned Vygotsky's treatment of learning as a process that occurs within a zone of proximal development. This is collective and explicit process, rather than a solitary one. For example, speaking, writing, and counting are first practiced out loud before becoming internalized (Crain, 2005). To become literate in social justice, we asked the students to apply tools that made their thinking, reflections, and argumentation explicit., Instructions and feedback served to scaffold students when they used these tools to explore their zone of proximal development, gradually shifting it towards new and more challenging tasks. In the SweSoc-course, seminars and peer review by other students were means to scaffold the students when demonstrating literacy in social justice.

Scaffolding supported students in differentiating between environmental justice and social justice. At the beginning of the course, students often conflated these terms or understood them to be synonymous. In the final essay, students who gave and received peer review had developed these arguments further and demonstrated the premises for their arguments in closer detail. One student began the essay's argument stating, "Swedish engineers are good 
at environmental justice, but not at social justice." Other examples from essays show students demonstrating an ability to distinguish between different stakeholders' perspectives, available resources and influence on urban planning in the name of sustainability.

We note that our approach to providing scaffolding in SweSoc did not decrease the overall workload of the teachers, but shifted it toward facilitation: to instruct the students in the use of the tools for analytical thinking, critical reflection, and peer review. The students' role, in turn, shifted from time-on-task participation towards being time managers who accounted for each stage in the explicit models to address the questions that we, the teachers, had formulated. In the area of social justice, identifying the critical questions is by implication linked to the ability to recognize different stakeholders' perspectives, presupposing the student's own ability for self-assessment or thinking about thinking. For a course of 200 students, neither the skills development nor the necessary dialogue or collaboration would have been possible if we had relied exclusively on teacher-student interaction. Rather, the purpose of students reviewing the texts of other students is based on guiding the review to assess features of the text that they have been instructed to demonstrate in their own writing. The point is to understand and suggest clarifications of the arguments used. During the course, we emphasized that seminar activities were not graded and that feedback should be constructive in order to create a learning environment that allowed students to raise new questions and test ideas relating to the course topics (cf. Biesta 2014). ${ }^{2}$

In our previous categorization of student comments from peer-review, we examined the degree to which the students demonstrated understanding of the explicit models. In the peerreview, while three out of four students used the formal language of the models, only one out of four discussed implicit aspects of the texts. For example, the students' texts had arguments whose implications they rarely spelled out (For an outline of the categories of feedback provided, see Author, 2015). We intended for students to use the explicit models in order to explicitly state the various elements of the texts, their argument and logic. Conversely, the models worked best with elements that were explicit themselves, for example what was the perspectives or sources used in the text or the results it had reached. In some cases, a student would challenge the questions of the assignment, providing alternative questions that they believed to be more relevant. We interpreted this as attempts by the student to reach beyond the format of the course, which is the whole point of the tools once the students have become proficient in their use.

Overall, our analysis of the students' writing illustrate both their views on social justice and how these views developed through readings, excursions, discussions, and writing. By discussing and reviewing each other's arguments, students could practice the metacognition of thinking through the role of the engineer with respects to people affected by their work.

\section{Epilogue and concluding remarks}

It's the end of the semester. We have just finished the last seminar with our students on the SweSoccourse. Now only the examination and course essay remain. One student lingers as the room clears, and then asks, "I now understand the models but I do not agree - can there not be other ways to analytical thinking or critical reflection?" Our answer would have been affirmative - indeed there are

\footnotetext{
${ }^{2}$ We acknowledge the valuable comments and suggestions by Amy E. Slaton on purpose of peer-review and comments on reward and motivation in instruction.
} 
other ways. We have argued that the three explicit models of analytical thinking, critical reflection, and peer review are condensed representations of entire fields of inquiry into how to think, reflect, and collaborate within the humanities. Engineering education should also cultivate a mentality where students take a critical view of critical analysis itself before they embark on their further studies, professional careers, and lives. But to introduce them to that process, we have argued for using the models as tools to scaffold their learning, as Lev Vygotsky outlined it. The tools are meant to be instructive, a point of reference that provide an initial sense of correct or incorrect demonstrations for how to think, reflect, and review arguments. In due time, the student can analytically and critically formulate and assess their own arguments. Over time, such habits shift their thinking about thinking, what we have referred to as metacognition, whereby they in turn may question the explicit models. The student may revise what they initially relied upon.

We have conceptualized thinking, reflection, and review as tools also to bring them into dialogue with what Rosalind Williams calls retooling - the shift in engineering education towards humanistic, reflexive, skills. We have called these skills for literacies and in particular discussed how to make engineering students literate about social justice. To retool engineering education towards literacy in social justice, students should focus on demonstrating arguments about social justice, not give summaries on literature that happen to use terms such as "social justice". The ability to assess and reformulate arguments will be of increasing relevance whenever engineering education seeks to incorporate wider societal goals.

By analyzing engineering students' views on solutions and challenges of addressing social justice in practice, we can improve our understanding of engineering skills required to work with social justice. Thereby, the study complements discussion and critiques of the relationships between society and engineering outlined in the rhetoric of engineering grand challenges, and contributes by discussing new roles for engineers in day-to-day challenges working with social justice.

Finally, many engineering students are unfamiliar with the literature and formats used for critical reflection within the humanities - it is imperative that any retooling to increase literacy in these domains neither overestimate what students know but conversely do not underestimate what they can be expected to understand. An introduction to analytical thinking, critical reflection and peer review should therefor be organized to build capacity and curiosity for further inquiries that by inference would problematize the very process through which we instructed that thinking and reflection in the first place.

\section{REFERENCES}

Biesta, G.J.J. (2014) The beautiful risk of education. Paradigm Publishers.

Biggs, J. and Tang, C. (2007) Teaching for Quality Learning at University. 2007: The Society for Research into Higher Education.

Bradley, K. Gunnarsson-Östling, U. and Isaksson, K. (2008) "Exploring Environmental Justice in Sweden - How to improve planning for environmental sustainability and social equity in an 'eco-friendly' context." Projections - MIT Journal of Planning, Vol. 8, 68-81.

CDIO (2015) http://www.cdio.org/cdio-history

Cech, E. (2012) Great problems of grand challenges: problematizing Engineering's understandings of its role in society. International Journal of Engineering, Social Justice and Peace, 1(2), 85-94.

Crain, W. (2005) Theories Of Development. Concepts and Applications. Fifth Edition ed. 2005: Pearson Education.

Cottrell, Stella. Critical Thinking Skills. Developing Effective Analysis and Argument. Palgrave Macmillan, 2005.

Cumming-Potvin, W. and Currie, J. (2013) Towards new literacies and social justice for engineering education, International Journal of Engineering, Social Justice and Peace, 2(1), 21-37. 
Dagens Nyheter (2014) Home with space for a large family. Article in newspaper Dagens Nyheter: Hem med plats för en stor familj. 2014-04-11. Retrieved from http://www.dn.se/sthlm/hem-med-plats-for-en-storfamilj/

Depew, Chauncey Mitchell (1893). Drexel Institute, Art, Science, and Industry: Dedication Ceremonies, Philadelphia.

Edström, K. and Kolmos. A. (2014) PBL and CDIO: complementary models for engineering education development. European Journal of Engineering Education, 38 (5), 539-555.

Elder, L.. and Paul, R. The Thinker's Guide to Analytical Thinking. How To Take Thinking Apart And What To Look For When You Do. The Foundation for Critical Thinking, 2007.

Elmgren, M., Henriksson, A-S., Universitetspedagogik [University pedagogy]. (2010), Uppsala University.

Enelund et al. (2013) Integration of education for sustainable development in the mechanical engineering curriculum. Australasian Journal of Engineering Education, 19(1), 1-12.

Engels, F. (1925) Dialectics of Nature. Moscow: Foreign Languages Publishing House.

Falcone, A., Knowles, S.G., Miller, J., Saraiva, T. and Slaton, A.E. (2016) Continuous Reinvention. A History of Engineering Education at Drexel University. In Richardson Dilworth and Scott Gabriel Knowles (eds.) Building Drexel. The University and Its City, 1891-2016. Temple University Press.

FEANI (2007) Engineering skills shortage in Europe - how do we solve it? FEANI position paper. European Federation of National Engineering Associations.

Gibbons, M (1998) Science's new social contract with society. Nature, 402: C81-84.

Harvey, L. (2013) Review of “Students, the University's Unspent Resource: Revolutionising Higher Education Through Active Student Participation and Transcending Boundaries: How CEMUS is Changing How We Teach, Meet and Learn. Higher Education Quarterly, 67(1): p. 95-106.

Healey, M., Jenkins, A. and Lea, J. et al. (2014) Developing research-based curricula in college-based higher education. The Higher Education Academy.

Herkert, J. (2012). Yogi meets Moses: Ethics, progress, and the grand challenges for engineering. International Journal of Engineering, Social Justice, and Peace, 1(2), 109-122.

Swedish National Agency for Higher Education (2006) Evaluation of Civil Engineering Programs at Swedish Universities and Institutions of Higher Education, Högskoleverket, Report 2006:31 R.

IFTF (2011) Future work skills 2010, Institute for the Future. Retrieved from http://www.iftf.org/futureworkskills/

JIIP (2012) Study to assist the European Research Area Board: Investing in Research and Innovation for Grand Challenges. Joint Institute for Innovation Policy, European Commission. Directorate Research and Innovation. Version January 2012.

Kabo, J., Tang, X., Nieusma, D., Currie, J., Wenlong, Hu., Baillie, C. "Visions of Social Competence: Comparing engineering education accreditation in Australia, China, Sweden and the United States", In American Society for Engineering Education, 2012.

Kaijser, A. (1998) Ingenjörer i takt med tiden?, in Vad är en ingenjör? (Edited by Ingela Björck), ISSN 1400-3902. ten Kate, L. (2011) “Uneasy Places. Monotheism, Christianity, and the Dynamic of the Unlikely in Sloterdijk's Work - Context and Debate", In Willem Schinkel Liesbeth Noordegraaf-Eelens. In Media Res. Peter Sloterdijk's Spherological Poetics of Being. Amsterdam University Press.

King, A. (1990) Enhancing Peer Interaction and Learning in the Classroom Through Reciprocal Questioning. American Educational Research Journal, 27(4): p. 664-687.

Knight, P., and Yorke, M., Learning, Curriculum and Employability in Higher Education. 2004, London/New York: Routledge, Falmer.

Lagerqvist, C. (2010) Vad är "högre" i den högre utbildningen? Om den högre utbildningens kvalitativa mervärde inom histo- rieämnet vid University of Oxford och Uppsala universitet [What is "higher" in higher education? On higher educations qualitative value within History at University of Oxford and Uppsala university]. Uppsala, 2010.

Lang, J. D., Cruse, S., McVey, F. D. and McMasters, J. (1999), Industry Expectations of New Engineers: A Survey to Assist Curriculum Designers. Journal of Engineering Education, 88, 43-51.

Lubchenco, J. (1998) Entering the Century of the Environment: A New Social Contract for Science. Science, New Series, 279 (5350): 491-497.

Mauser, W., Klepper, G., Rice, M., Schmaulzbauer, B.S. et al. (2013) Transdisciplinary global change research: The co-creation of knowledge for sustainability. Current Opinion in Environmental Sustainability, 5(3-4): 420-431. 
NAE (2008). Grand challenges for engineering. Washington, DC: National Academies Press. National Academy of Engineering. Retrieved from http://www.engineeringchallenges.org/?ID=11574

Nieusma, D. and Tang, X. (2012) The unbalanced equation: technical opportunities and social barriers in the NAE grand challenges and beyond. International Journal of Engineering, Social Justice and Peace, 1(2), 137151.

Niewoehner, R.J. (2006) A critical thinking model for engineering, in 2nd international CDIO Conference, Linköping.

Sochacka, N.W. et al. (2014) Stories 'Told' about Engineering in the Media: Implications for attracting diverse groups to the profession. Paper presented at the Frontiers in Education, Madrid, Spain.

Svanström, M. et al. (2012) Embedding of ESD in Engineering Education - Experiences from Chalmers University of Technology. International Journal of Sustainability in Higher Education, 13(3), 279-292.

Swedish Higher Education Ordinance (2015)

Source:http://www.uhr.se/sv/Information-in-English/Laws-and-regulations/The-Higher-EducationOrdinance/Annex-2/

Rawls, J. (1971) A theory of justness. Retrieved from Internet Encyclopedia of Philosophy: John Rawls. http://www.iep.utm.edu/rawls/\#SH2g

de los Reyes, P. et al. (2014) Bilen brinner...men problemen är kvar [The car is burning...but the problem remains]. Stockholmia förlag, 2014.

Richard, P. and Elder, L. (2005) A Miniature Guide For Students and Faculty To The Foundations of Analytical Thinking. How to Take Thinking Apart And What To Look For When You Do. The Foundation for Critical Thinking.

UKÄ (2013) Utvärdering av utbildningar inom ingenjörs- och

Teknikvetenskap, arbetssätt, resultat, analys och reflektioner [Evaluation of engineering educations: approach, results, analysis and reflections], 2013-10-28.

Vaara, E., Sorsa, V. and Pälli, P. (2010) On the force of potential strategy texts: a critical discourse analysis of a strategic plan and its power in a city organization. Organization, 17(6), 685-702.

Vygotsky, L.S., (1978) Tool and symbol in children's development, in L.S. Vygotsky: Mind in society, V.J.-S. M. Cole, S. Scribner, \& E. Souberman, Editor. Harvard University Press.: Cambridge, MA.

Walther, J., Sochacka, N. W., \& Kellam, N. N. (2013). Quality in Interpretive Engineering Education Research: Reflections on an Example Study. Journal of Engineering Education, 102(4), 626-659. doi: 10.1002/jee.20029

Weinburg, S. and McGrew, S. (2016) Why Students Can't Google Their Way to the Truth. Fact-checkers and students approach websites differently. Education week, 1 November 2016. Available online: http://www.edweek.org/ew/articles/2016/11/02/why-students-cant-google-their-way-to.html

Williams, R. (2002), Retooling. A Historian Confronts Technological Change, The MIT Press, Cambridge, Massachusetts.

Other sources:

SweSoc (2013) Course Survey Fall 2013.

SweSoc (2014) Course Survey Spring 2014.

Course material (2014) Lecture on critical analysis

Author (2015) Paper presented at American Society for Engineering Education 


\title{
Appendix 1: Degree ordinance Sweden 2015
}

\author{
Degree of Master of Science in Engineering [Civilingenjörsexamen]
}

\section{Scope}

A Degree of Master of Science in Engineering is awarded after the student has completed the courses required to gain 300 credits.

\section{Outcomes}

For a Degree of Master of Science in Engineering the student shall demonstrate the knowledge and skills required to work autonomously as a graduate engineer.

\section{Knowledge and understanding}

For a Degree of Master of Science in Engineering the student shall

- demonstrate knowledge of the disciplinary foundation of and proven experience in his or her chosen field of technology as well as insight into current research and development work, and

- demonstrate both broad knowledge of his or her chosen field of technology, including knowledge of mathematics and the natural sciences, as well as a considerable degree of specialised knowledge in certain areas of the field.

Competence and skills

For a Degree of Master of Science in Engineering the student shall

- demonstrate the ability to identify, formulate and deal with complex issues autonomously and critically and with a holistic approach and also to participate in research and development work and so contribute to the formation of knowledge

- demonstrate the ability to create, analyse and critically evaluate various technological solutions

- demonstrate the ability to plan and use appropriate methods to undertake advanced tasks within predetermined parameters

- demonstrate the ability to integrate knowledge critically and systematically as well as the ability to model, simulate, predict and evaluate sequences of events even with limited information

- demonstrate the ability to develop and design products, processes and systems while taking into account the circumstances and needs of individuals and the targets for economically, socially and ecologically sustainable development set by the community

- demonstrate the capacity for teamwork and collaboration with various constellations, and

- demonstrate the ability to clearly present his or her conclusions and the knowledge and arguments on which they are based in speech and writing to different audiences in both national and international contexts.

Judgment and approach

For a Degree of Master of Science in Engineering the student shall

- demonstrate the ability to make assessments informed by relevant disciplinary, social and ethical aspects as well as awareness of ethical aspects of research and development work

- demonstrate insight into the possibilities and limitations of technology, its role in society and the responsibility of the individual for how it is used, including both social and economic aspects and also environmental and occupational health and safety considerations, and

- demonstrate the ability to identify the personal need for further knowledge and undertake ongoing development of his or her skills.

\section{Independent project (degree project)}

A requirement for the award of a Degree of Master of Science in Engineering is completion by the student of an independent project (degree project) for at least 30 credits.

\section{Miscellaneous}

Specific requirements determined by each higher education institution itself within the parameters of the requirements laid down in this qualification descriptor shall also apply for a Degree of Master of Science in Engineering. 


\section{Appendix 2}

Illustrations of word trees used in textual analysis of student reflections in essays relating to excursions to suburbs Husby and Hammarby Sjöstad, using NVivo 11.

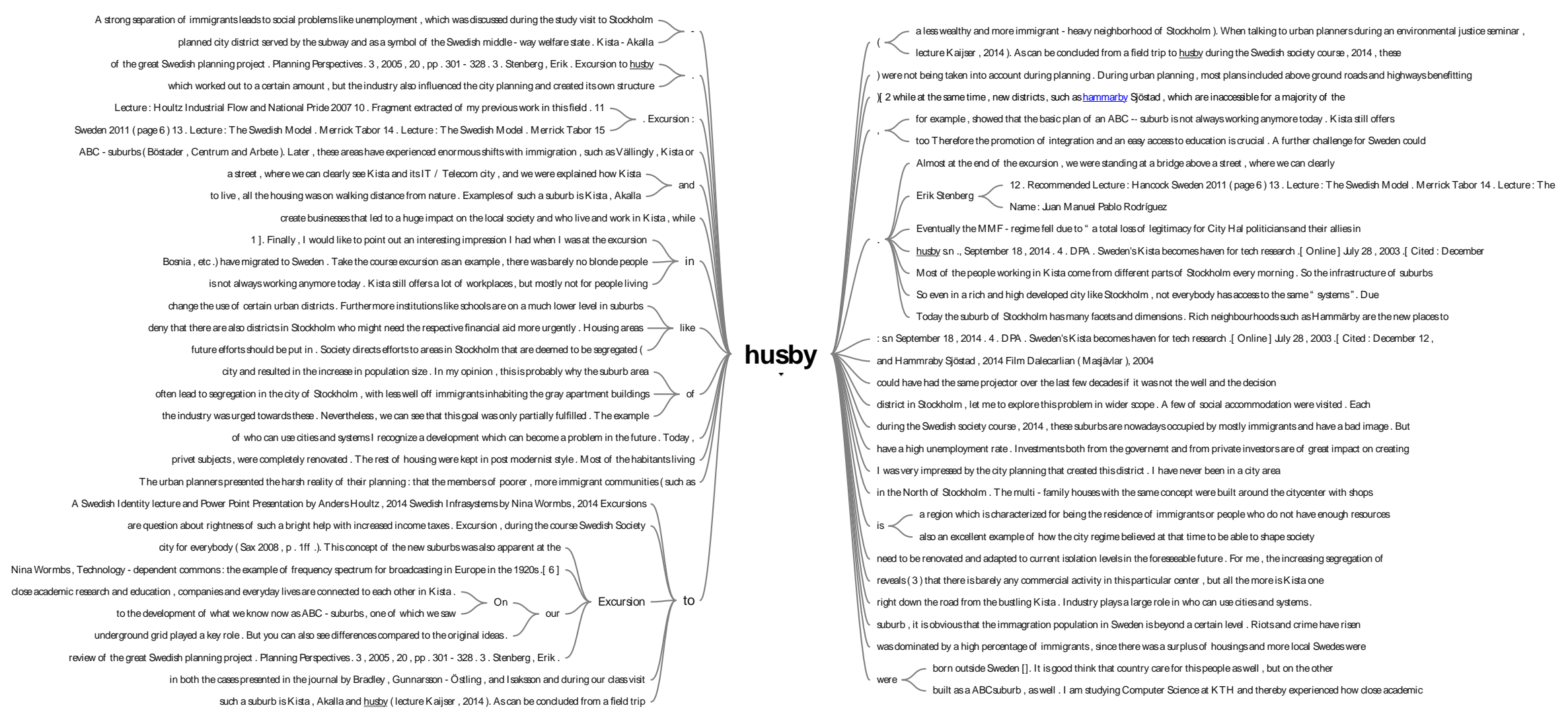




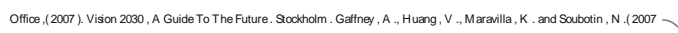

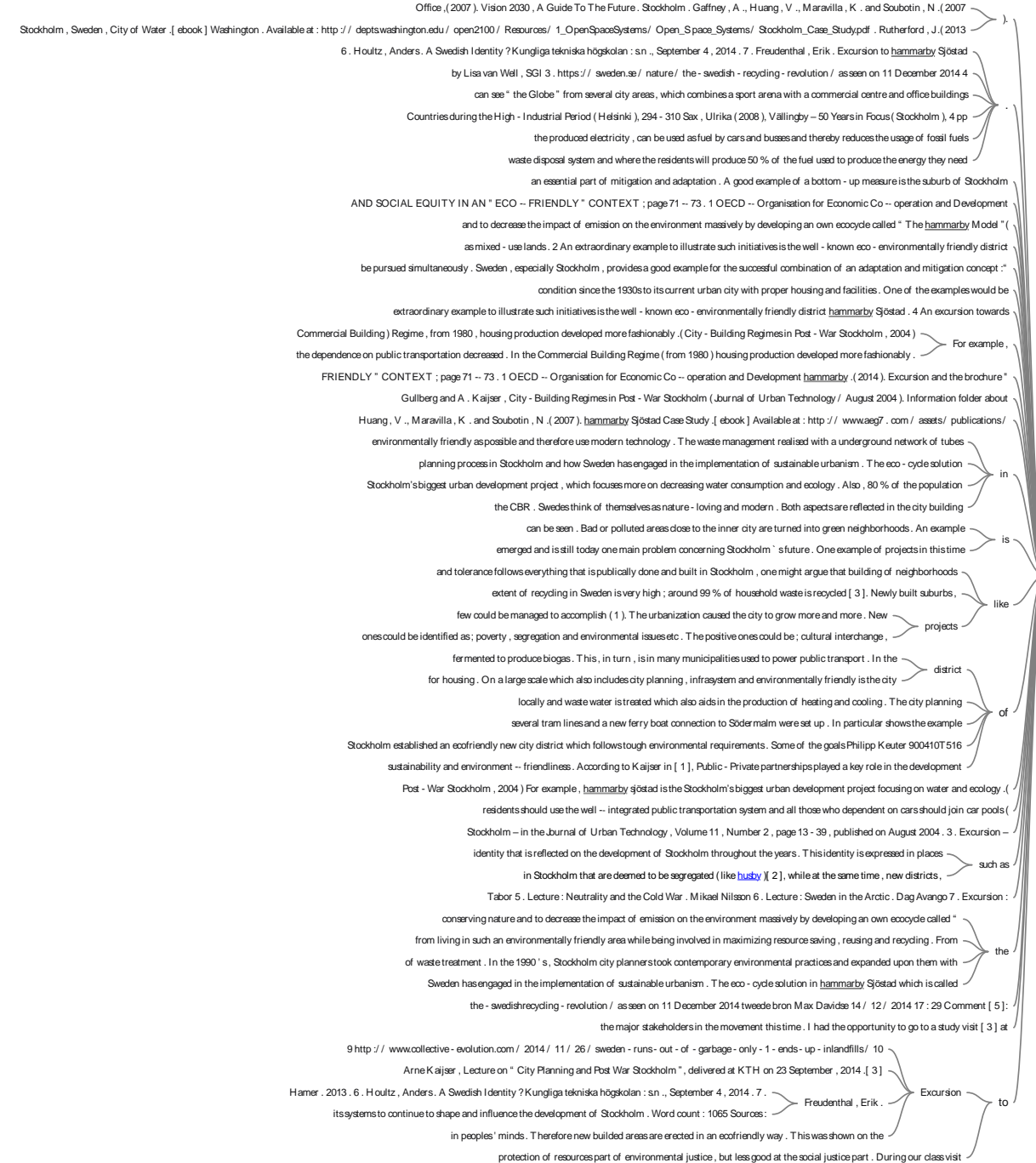

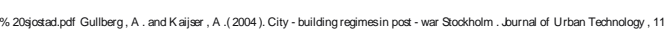

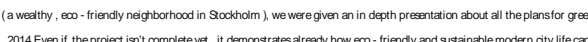

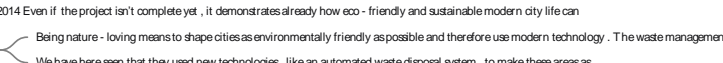

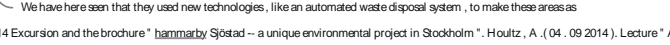

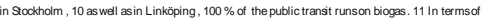

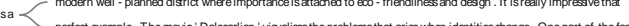

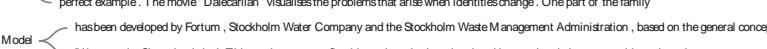

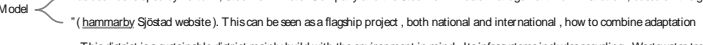

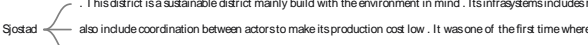

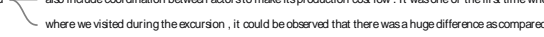

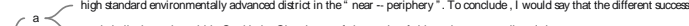

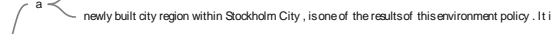

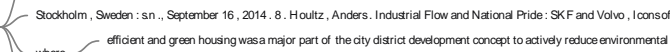

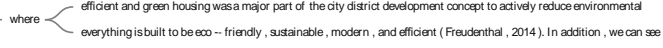

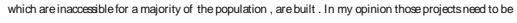

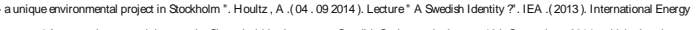

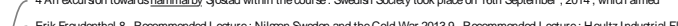

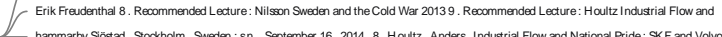

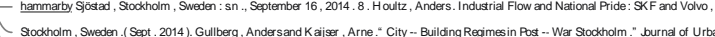

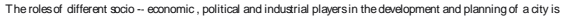

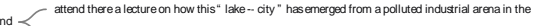

